\title{
LAÇO FRATERNO: \\ UM ESTUDO A PARTIR DA EXPERIÊNCIA CLÍNICA NO CTI PEDIÁTRICO
}

As relações fraternas, assim como a fraternidade, tem sido objeto de estudo de diversos autores psicanalistas contemporâneos. O presente estudo tem como objetivo estudar a importância do laço fraterno na constituição do sujeito e quais são suas repercussões no ambiente intensivista pediátrico, tendo em vista que alguns hospitais realizam visitas dos irmãos às crianças internadas. É contemplada a importância da fratria na construção da subjetividade, além do valor da fraternidade e dos laços de amizade e solidariedade constatados a partir da experiência clínica e corroborados pelas discussões clínicas recentes.

\section{BANCA:}

Silvia Maria Abu-Jamra Zornig (Orientadora)

Denise Streit Morsch

Maria Inês Garcia de Freitas Bittencourt

Data da defesa: 23/02/2010 